\title{
Chemometrics applied to the incorporation of omega-3 in tilapia fillet feed flaxseed flour
}

Márcia Fernandes NISHIYAMA ${ }^{1,2}$, Aloisio Henrique Pereira de SOUZA ${ }^{1}$, Aline Kirie GOHARA ${ }^{1}$, Hevelyse Munise Celestino dos SANTOS ${ }^{1}$, Carlos Antonio Lopes de OLIVEIRA ${ }^{3}$, Ricardo Pereira RIBEIRO ${ }^{3}$, Nilson Evelázio de SOUZA ${ }^{4}$, Sandra Terezinha Marques GOMES ${ }^{5}$, Makoto MATSUSHITA ${ }^{5 *}$

\begin{abstract}
This study evaluated the effect of adding flaxseed flour to the diet of Nile tilapia on the fatty acid composition of fillets using chemometrics. A traditional and an experimental diet containing flaxseed flour were used to feed the fish for 60 days. An increase of 18:3 n-3 and 22:6 n-3 and a decrease of 18:2 n- 6 were observed in the tilapia fillets fed the experimental diet. There was a reduction in the n-6:n-3 ratio. A period of 45 days of incorporation caused a significant change in tilapia chemical composition. Principal Component Analysis showed that the time periods of 45 and 60 days positively contributed to the total content of $\mathrm{n}-3$, LNA, and DHA, highlighting the effect of omega-3 incorporation in the treatment containing flaxseed flour.
\end{abstract}

Keywords: Nile tilapia; essential fatty acids; flaxseed flour; principal component analysis.

\section{Introduction}

The intake of fish meat and fish oil has attracted the interest of researchers due to their beneficial effects on human health (Givens \& Gibbs, 2006; Kirkhus et al., 2012). The lipid fraction in fish is composed of polyunsaturated fatty acids; the omega- 6 and omega-3 have gained particular attention because they have important metabolic functions, including pro- and antiinflammatory effects, respectively. The recommended n-6:n-3 ratio ranges from 1:1 to 4:1 in order to avoid adverse effects on metabolism. However, the Western diets provide ratios of between 10:1 and 20:1, and there are reports of 50:1 (Ratnayake \& Galli, 2009).

Some fish species have an enzymatic system (elongases and desaturases) that enables the conversion of linoleic acid (LA, 18:2 n-6) into arachidonic acid (AA, 20:4 n-6) and alpha-linolenic acid (ALA, 18:3 n-3) into eicosapentaenoic (EPA, 20:5 n-3) and docosahexaenoic acids (DHA, 22:6 $\mathrm{n}-3)$. These compounds are considered essential fatty acids because they cannot be synthesized by the human body and must be taken in through the diet (Simopoulos, 2011). EPA and DHA are associated with metabolic and biochemical processes involved in the prevention of cardiovascular disease, psoriasis, arthritis, atherosclerosis, eczema, cancer, reducing depression risk, diabetes, rheumatoid arthritis, osteoporosis, cognitive decline, and neurologic dysfunctions such as Alzheimer and schizophrenia (Mateos et al., 2012; Ottestad et al., 2012).

Marine fish are considered rich in omega-3 fatty acids due to ingestion of plankton (a source of LNA). The levels of EPA and DHA in tilapia fillets in captivity are dependent on the lipid profile of the feed offered, and their fatty acid composition can be improved through the fish farming system (Zanqui et al., 2013).

The use of vegetable oil from soybean, rapeseed, sunflower, and flaxseed has been evaluated in diets of fish species of temperate climates, and it has shown no effects on growth performance; however, some differences in the lipid composition of the muscle tissue according to the oil used have been observed (Bahurmiz \& Ng, 2007).

Flaxseed has $51.8-60.4 \%$ ALA and is considered an excellent omega-3 source (Ryan et al., 2007). The use of flaxseed to enrich foods without causing radical changes in eating habits is promising (Pagamunici et al., 2014a, 2014b; Souza et al., 2014). Multivariate analysis enables extracting more information when compared to univariate analysis (Luciano \& Naes, 2009), which is a chemometric tool allows for pattern recognition, the gathering of information, reduction of data dimensionality and the organization of data in different groups according to similarities in an easier to understand structure (Matos et al., 2003). Principal component analysis (PCA) is based on performing linear comparisons of the original variables. The principal components (PC) are mutually orthogonal and explain the variance decreases with an increase in the PC number (Correia \& Ferreira, 2007). Therefore, this study evaluated the effect of the addition of flaxseed flour to the diet of Nile tilapia on the fatty acid composition of its muscle tissue as a function of the feeding time using chemometrics.

\footnotetext{
Received 09 Apr., 2014

Accepted 06 June, 2014 (006341)

${ }^{1}$ Center of Agricultural Sciences, State University of Maringá - UEM, Maringá, PR, Brazil

${ }^{2}$ Federal University of South Frontier - UFFS, Realeza, PR, Brazil

${ }^{3}$ Department of Animal Science, State University of Maringá -UEM, Maringá, PR, Brazil

${ }^{4}$ Federal Technological University of Paraná - UTFPR, Londrina, PR, Brazil

${ }^{5}$ Department of Chemisty, State University of Maringá - UEM, Maringá, PR, Brazil, e-mail: mmakoto@uem.br

${ }^{*}$ Corresponding author
} 


\section{Materials and methods}

The experiment lasted 60 days and was performed in the Crow River, in the city of Diamante do Norte, Parana, Brazil $\left(22^{\circ} 39^{\prime} \mathrm{S} ; 052^{\circ} 46^{\prime} \mathrm{O}\right)$. A total of 400 tilapias with an initial live weight of $245 \mathrm{~g}$ were distributed into eight cages with a unit volume of $1.2 \mathrm{~m}^{3}(1.0 \times 1.0 \times 1.2 \mathrm{~m}$ high $)$ and at density of 50 fishes per cage in a completely randomized design with two treatments and four replications; each tank was considered an experimental unit.

Two feeds were prepared in this experiment: a control feed, using soybean oil, and an experimental feed, where soybean oil was substituted for flaxseed flour $\left(50 \mathrm{~g} \mathrm{~kg}^{-1}\right)$, as shown in Table 1. The experimental diets were formulated according to the nutritional requirements of the species (National Research Council, 1993). The fish were fed twice daily, at 9am and 3pm, at $2 \%$ of totl biomass.

Three individuals were collected per experimental unit starting at time zero (before starting treatment) and every 15 days up to 60 days. After every collection, the fish were killed by an overdose of xylocaine $\left(10 \mathrm{~g} \mathrm{~L}^{-1}\right)$, weighed, gutted, and filleted; the fillets were ground in a multiprocessor, homogenized, and packed in polyethylene bags. The samples were stored in a freezer $\left(-24^{\circ} \mathrm{C}\right)$ under a nitrogen atmosphere until analyses.

\subsection{Analysis}

Moisture, crude protein, and ash were determined according to Cunniff (1998), and 6.25 was used as the conversion factor of total nitrogen to crude protein. Total lipids were extracted according to the method proposed by Bligh \& Dyer (1959).

To determine their fatty acid composition, the lipids were converted into fatty acid methyl esters (FAME) and methylated according to Hartman \& Lago (1973). The FAME were separated in a gas chromatograph CP-3380 (Varian, USA) fitted with a flame ionization detector following the conditions used by Fuchs et al. (2013).

The retention times were compared to those of standard methyl esters (Sigma, USA). The fatty acids were identified using tricosanoic acid methyl esters (Sigma, USA) as internal standards, as described by Joseph \& Ackman (1992). The peak areas were determined using the Star 5.0 software (Varian, USA), and the fatty acid concentrations were expressed in $\mathrm{mg}$ FA per $g$ of total lipids.

\subsection{Ethical aspects and biosecurity}

This study was approved by the Ethics Committee on Animal Use in Trials of Maringa State University, File No. 011/2011, 036/2011.

\subsection{Statistical and multivariate analysis}

The Fatty acid composition and physicochemical analyses were carried out in triplicate. The results were submitted to variance analysis (ANOVA), and the means were compared using Tukey's post hoc and the Student " $\mathrm{t}$ " tests by comparing the control and flaxseed treatment as a function of feeding time. Multivariate analysis was performed applying the Principal Component Analysis (PCA). The average of the contents of LA, AA, LNA, EPA, DHA, SFA, MUFA, PUFA, n-3, n-6, n-6:n-3; PUFA:SFA, and proximal composition that were obtained in three individual batches was used. The averages were autoscaled using the NIPALS algorithm. Regression analyses were performed to verify the incorporation of LA, LNA, and DHA

Table 1. Control and flaxseed feed formulations.

\begin{tabular}{|c|c|c|}
\hline \multirow{2}{*}{$\begin{array}{l}\text { Ingredients } \\
\quad\left(\mathrm{g} \mathrm{kg}^{-1}\right)\end{array}$} & \multicolumn{2}{|c|}{ Feeds } \\
\hline & Control & Flaxseed \\
\hline Corn & 389.6 & 408.6 \\
\hline Soybean meal & 320.0 & 320.0 \\
\hline Fish meal & 120.0 & 120.0 \\
\hline Wheat bran & 80.0 & 80.0 \\
\hline Rice flour & 50.0 & 0.0 \\
\hline Flaxseed whole meal & 0.0 & 50.0 \\
\hline Soybean oil & 19.0 & 0.0 \\
\hline Dicalcium phosphate & 6.0 & 6.0 \\
\hline Salt & 5.0 & 5.0 \\
\hline Vitamin and mineral supplement $\mathrm{t}^{\mathrm{a}}$ & 5.0 & 5.0 \\
\hline Lysine & 1.2 & 1.2 \\
\hline Propionic acid & 1.0 & 1.0 \\
\hline Vitamin C & 0.8 & 0.8 \\
\hline Methionine & 1.0 & 1.0 \\
\hline Threonine & 1.0 & 1.0 \\
\hline Tryptophan & 0.2 & 0.2 \\
\hline $\mathrm{BHT}^{\mathrm{b}}$ & 0.2 & 0.2 \\
\hline \multicolumn{3}{|l|}{ Proximal composition ${ }^{\mathrm{c}}\left(\mathrm{g} \mathrm{kg}^{-1}\right)$} \\
\hline Moisture & $526.9 \pm 6.5$ & $525.4 \pm 5.8$ \\
\hline Crude protein & $301.3 \pm 4.7$ & $280.7 \pm 5.1$ \\
\hline Ash & $61.1 \pm 0.7$ & $78.5 \pm 0.3$ \\
\hline Total lipid & $104.5 \pm 0.3$ & $53.7 \pm 2.4$ \\
\hline \multicolumn{3}{|l|}{ Fatty acid ${ }^{\mathrm{d}}\left(\mathrm{mg} \mathrm{g}^{-1}\right.$ total lipid $)$} \\
\hline $14: 0$ & $7.83 \pm 0.28$ & $5.13 \pm 0.12$ \\
\hline 16:0 & $155.54 \pm 5.44$ & $124.38 \pm 2.45$ \\
\hline $18: 0$ & $15.37 \pm 0.49$ & $10.16 \pm 0.17$ \\
\hline $16: 1 n-7$ & $37.14 \pm 1.31$ & $41.34 \pm 0.75$ \\
\hline $18: \ln -9$ & $295.69 \pm 9.51$ & $268.62 \pm 6.22$ \\
\hline $18: 2 n-6(L A)$ & $407.96 \pm 13.29$ & $296.12 \pm 7.27$ \\
\hline $18: 3 n-3$ (LNA) & $30.67 \pm 1.00$ & $177.40 \pm 5.16$ \\
\hline \multicolumn{3}{|l|}{ Parameters } \\
\hline SFA & $178.74 \pm 5.47$ & $139.66 \pm 2.46$ \\
\hline MUFA & $332.83 \pm 9.60$ & $309.96 \pm 6.27$ \\
\hline PUFA & $438.63 \pm 13.33$ & $473.52 \pm 8.92$ \\
\hline PUFA:SFA & $2.45 \pm 0.04$ & $3.39 \pm 0.03$ \\
\hline$n-6: n-3$ & $13.30 \pm 0.05$ & $1.67 \pm 0.04$ \\
\hline
\end{tabular}

SFA: total saturated fatty acids; MUFA: total monounsaturated fatty acids; PUFA: total polyunsaturated fatty acids; $n-6$ : total omega- 6 fatty acids and n-3: total omega-3 fatty

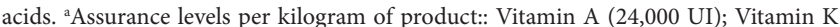
(30 mg); Vitamin B1 (40 mg); Vitamin B6 (35 mg); Vitamin ( $80 \mathrm{mg})$; Folic acid (12 mg); Pantothenate Calcium (100 mg); Vitamin C (600 mg); Biotin (2 mg); Cholline (1000 mg); iron (200 mg); Copper (35 mg); Manganese (100 mg); Zinc (240 mg); Iodine (1.6 mg); Cobalt $(0.8 \mathrm{mg})$. ${ }^{\mathrm{b}}$ Butil Hidroxy Toluene. ${ }^{\mathrm{c}}$ Mean and standard deviation. ${ }^{\mathrm{d}}$ Other fatty acids identified: $14: 1 n-9,14: 1 n-7,15: 0,16: 1 n-9,16: 1 n-5,17: 0,17: 1 n-11,17: 1 n-9,17: 1 n-7$, $18: 1 n-7,18: 1 n-11,18: 1 n-5,20: 0,20: 1 n-9,20: 1 n-7,21: 0,20: 2 n-6,20: 3 n-6,22: 0,22: 4 n-6$, 22:5n-6, 24:0, 24:1n-9. 
fatty acids into the muscle tissue of fish fed with flaxseed. The software Statistica (StatSoft, 2007), version 8.0, was used with a $5 \%(\mathrm{p}<0.05)$ significance level for rejection of the null hypothesis.

\section{Results and discussion}

The proximal and fatty acid composition of the diets used in the experiment are shown in Table 1. The diets had different fatty acid compositions. The diet containing flaxseed flour had a higher content of LNA because of the fatty acid composition of this ingredient.

Table 2 shows the proximal composition of muscle tissues analyzed in each treatment. Moisture and ash content did not differ $(\mathrm{p}<0.05)$ during the study period for both treatments. In the control diet there was a significant difference $(p<0.05)$ in protein content between the experimental times, but there was no significant difference $(\mathrm{p}<0.05)$ between the diets according to the $\mathrm{t}$ test. In the present study, total lipids ranged from 2.5 to $3.5 \%$ without significant difference $(\mathrm{p}<0.05)$ between the experimental times and the treatments. Simões et al. (2007) obtained a proximal composition similar to that of the present study.

Table 3 and Figure 1 show the principal component analysis (PCA). The NIPALS algorithm enabled us to select PC1 and PC2, which were significant $(\mathrm{p}<0.05)$ and explained 54.50 and $38.99 \%$ of the data variance, respectively. As can be seen in Figure 1, PC1 allowed to set apart the times 0, 15, and 30 days for both treatments and 45 days for the flaxseed treatment due to the positive contributions of the contents of ash and moisture. Analyzing PC2 (Figure 1 and Table 3), the time periods of 45 and 60 days indicate that both diets positively contributed to increase the crude protein and moisture content.

As for the fatty acids, an increase in n-3 PUFA was observed over time in the treatment supplemented with flaxseed, particularly LNA, (Table 3 ). The incorporation can be evidenced by linear regression analysis using the equation: $\mathrm{Y}=$ $9.2880+0.2274^{*} \mathrm{X}$, with $\mathrm{R}^{2}=0.9087$ and high Pearson correlation coefficient $r=0.9532$. This may demonstrate the influence of LNA from the flaxseed on the lipid composition, with an increase of 52\% after 60 days. The studies of Justi et al. (2003), Matsushita et al. (2006) and Aguiar et al. (2011), which included the use of flaxseed aiming at the incorporation of $n-3$ into muscle tissue, also described satisfactory effects; however, these authors used flaxseed oil. Analyzing the time periods of 45 and 60 days, it can be seen that there was no significant difference $(p<0.05)$ in the incorporation of LNA. This effect was described by Tonial et al. (2009), when assessing the addition of flaxseed oil as a source of n-3 in the diet adult tilapia. These authors found an increase in the levels of LNA in the muscle tissue up to 45 days, which remained constant until the treatment period of 90 days was completed.

As can be seen in Figure 2, PC1 allowed to distinguish the control treatment because of the positive contributions of LA, AA, SFA, MUFA, n-6 and n-6:n-3. Analyzing PC1 and PC2 (Figure 2 and Table 3), the time periods of 15 and 60 days of the flaxseed treatment showed positive contributions to the

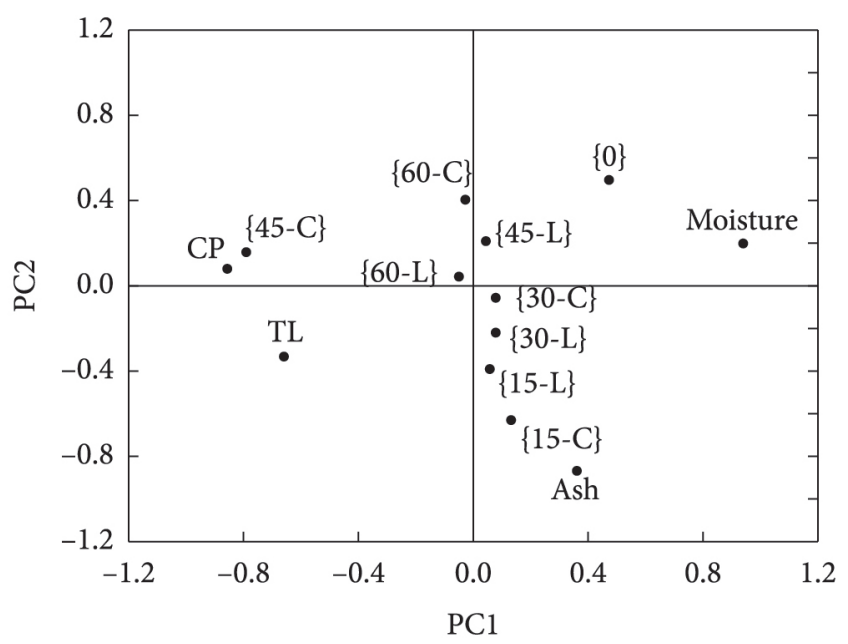

Figure 1. Principal component analysis of proximal composition of the treatments. PC: Principal Component. CP: crude protein. TL: Total lipid. $\{0\}$ : initial time of the experiments of the control and linseed treatments; $\{15-C\},\{30-C\},\{45-C\}$ and $\{60-C\}$ : experimental times of the control treatment; $\{15-\mathrm{L}\},\{30-\mathrm{L}\},\{45-\mathrm{L}\}$ and $\{60-\mathrm{L}\}$ : experimental times of the linseed treatment.

Table 2. Proximal composition of Tilapia fillets.

\begin{tabular}{|c|c|c|c|c|c|}
\hline \multirow{2}{*}{ Parameters } & \multicolumn{5}{|c|}{ Time (days) } \\
\hline & 0 & 15 & 30 & 45 & 60 \\
\hline Moisture & $76.17^{\mathrm{Aa}} \pm 0.46$ & $74.35^{\mathrm{Ac}} \pm 0.67$ & $74.61^{\mathrm{Ac}} \pm 0.09$ & $72.34^{\mathrm{Bb}} \pm 0.82$ & $74.26^{\mathrm{Ac}} \pm 1.09$ \\
\hline Total lipid & $2.53^{\mathrm{Aa}} \pm 0.23$ & $3.12^{\mathrm{Aa}} \pm 0.70$ & $2.80^{\mathrm{Aa}} \pm 0.35$ & $3.55^{\mathrm{Aa}} \pm 0.75$ & $2.96^{\mathrm{Aa}} \pm 0.43$ \\
\hline Crude protein & $20.22^{\mathrm{Ab}} \pm 0.77$ & $20.59^{\mathrm{Ab}} \pm 0.37$ & $21.11^{\mathrm{Aab}} \pm 0.16$ & $22.60^{\mathrm{Aa}} \pm 0.83$ & $20.67^{\mathrm{Ab}} \pm 1.12$ \\
\hline Ash & $1.04^{\mathrm{Aa}} \pm 0.01$ & $1.18^{\mathrm{Bb}} \pm 0.02$ & $1.16^{\mathrm{Ab}} \pm 0.06$ & $1.08^{\mathrm{Aab}} \pm 0.10$ & $1.10^{\mathrm{Aab}} \pm 0.03$ \\
\hline Total lipid & $2.53^{\mathrm{Aa}} \pm 0.23$ & $3.20^{\mathrm{Aa}} \pm 0.30$ & $3.11^{\mathrm{Aa}} \pm 0.22$ & $2.58^{\mathrm{Aa}} \pm 0.46$ & $2.78^{\mathrm{Aa}} \pm 0.27$ \\
\hline Crude protein & $20.22^{\mathrm{Aa}} \pm 0.77$ & $20.40^{\mathrm{Aa}} \pm 0.39$ & $20.81^{\mathrm{Aa}} \pm 0.27$ & $21.17^{\mathrm{Ba}} \pm 0.78$ & $21.20^{\mathrm{Aa}} \pm 0.87$ \\
\hline
\end{tabular}

Means obtained from analysis performed in triplicates followed by standard deviation. Same uppercase letters in the same column for the same parameter analyzed do not show significant difference $(\mathrm{p}<0.05)$ between the treatments. Same lowercase letters in the same line do not show significant difference $(\mathrm{p}<0.05)$ over time. 
Table 3. Eigen analysis of the correlation matrix loadings of the significant principal component (PC) of the fatty acids and proximal composition of the treatments.

\begin{tabular}{lcc}
\hline & Proximal composition & \\
\hline \multicolumn{3}{c}{ PC1 } \\
\hline Eigenvalues & 3.0805351 & 1.9881894 \\
\% Total variance & 23.696424 & 15.293765 \\
Moisture & 0.942311 & 0.197904 \\
Ash & 0.359125 & -0.870550 \\
Total Lipid & -0.658702 & -0.337443 \\
Protein & -0.857940 & 0.084077 \\
\hline & Fatty acid & \\
\hline & PC1 & PC2 \\
\hline Eigenvalues & 8.3980760 & 3.0477510 \\
\% Total variance & 39.990838 & 14.5131 \\
18:2n-6 (LA) & 0.951105 & 0.103293 \\
18:3n-3 (LNA) & -0.946017 & 0.107835 \\
20:4n-6 (AA) & 0.949895 & -0.030956 \\
20:5n-3 (EPA) & -0.351285 & -0.283959 \\
22:6n-3 (DHA) & -0.874725 & 0.106105 \\
SFA & 0.579596 & -0.726977 \\
MUFA & 0.260461 & -0.543966 \\
PUFA & 0.655780 & 0.528182 \\
n-6 & 0.942007 & 0.255775 \\
n-3 & -0.972420 & 0.102177 \\
n-6:n-3 & 0.988349 & -0.095847 \\
PUFA:SFA & 0.224829 & 0.899655 \\
\hline CC: & &
\end{tabular}

PC: Principal component. SFA: total saturated fatty acids; MUFA: total monounsaturated fatty acids; PUFA: total polyunsaturated fatty acids; $n-6$ : total omega- 6 fatty acids and n-3: total omega-3 fatty acids.

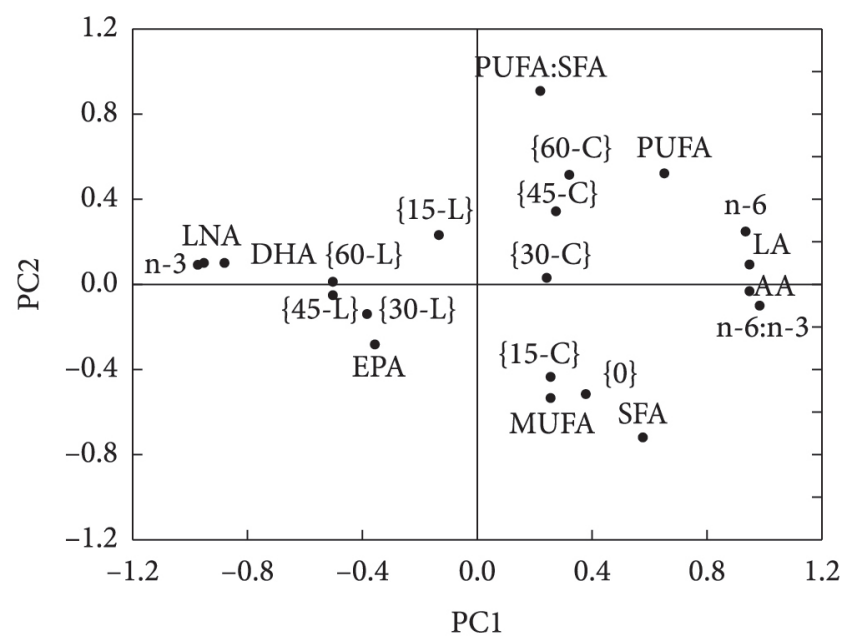

Figure 2. Principal component analysis of essential fatty acids and the relationship between them in both treatments. AA: arachidonic acid; LNA: alpha-linolenic acid; EPA: eicosapentanoic acid; DHA: docsahexaenoic acid; LA: linolenic acid; SFA: total saturated fatty acids; MUFA: total monounsaturated fatty acids; PUFA: total polyunsaturated fatty acids; $n-6$ : total omega- 6 fatty acids and n-3: total omega- 3 fatty acids. $\{0\}$ : initial time of the experiments of the control and linseed treatments; $\{15-C\},\{30-C\},\{45-C\}$ and $\{60-C\}$ : experimental times of the control treatment; $\{15-\mathrm{L}\},\{30-\mathrm{L}\},\{45-\mathrm{L}\}$ and $\{60-\mathrm{L}\}$ : experimental times of the linseed treatment. total content of n-3, LNA and DHA, highlighting the effect of incorporation of omega 3 fatty acids through supplementation with flaxseed flour.

As can be seen in Table 3, the EPA content (20:5n-3) of fillets from fish fed with flaxseed did not differ significantly through the time. The fishes have two enzymes, elongase and desaturase, which act in the bioconversion of LNA into EPA. They also convert EPA into DPA (docosapentaenoic acid) and DPA into DHA. Therefore, EPA and DPA are considered secondary metabolites and are converted into DHA via metabolic pathway. Due this conversion, some variations in the contents of EPA and DPA may be observed (Perini et al., 2010). Table 4 also shows that feed supplemented with flaxseed flour significantly increased $(p<0.05)$ the level of DHA $(22: 6 n-3)$ in the fillets. This increase was around $73 \%$ (Table 4 ). The incorporation of DHA could be verified by linear regression analysis using the equation: $\mathrm{Y}=7.9040+0.0908^{*} \mathrm{X}$, with $\mathrm{R}^{2}=0.9098$ and high Pearson correlation coefficient $r=0.9538$. These data confirm the fatty acid conversion of in the fish metabolism during farming.

In the control treatment, there were significant variations $(p<0.05)$ in the levels of EPA, but DHA remained constant during the experimental period. According to Visentainer et al. (2003), Nile tilapia has low levels of LNA, EPA, DHA, and other n-3 fatty acids in their muscle tissue when compared to those of marine fish, according to Luzia et al. (2003). Blanchet et al. (2005) found $0.322 \mathrm{~g} \mathrm{~kg}$ of DHA in wild trout and tilapia fed with flaxseed flour.

The level of LA (18:2 n-6) in the control treatment varied throughout the experiment (Table 4); however, there was no significant difference between $\mathrm{T} 0$ and T60. In the flaxseed treatment, there was a significant decrease of $15 \%(\mathrm{p}<0.05)$ (Table 4). This was probably due to the absence of soybean oil (as a source of $n-6)$ in the feed. Using regression analysis, a decrease in LA was verified by the equation: $\mathrm{Y}=128.3360-0.3540^{\star} \mathrm{X}$, with $\mathrm{R}^{2}=0.8355$ and Pearson correlation coefficient $\mathrm{r}=0.9140$. During the experiment, the concentration of AA decreased in the flaxseed treatment. This fact may be justified by the competition for $\Delta 6$ desaturase enzyme, which catalyze the conversion of LA and LNA into AA and DHA, respectively. The n-6:n-3 ratio of the flaxseed diet was close to $1: 1$, but the fish metabolism has a preference for LNA fatty acid resulting in a lower concentration of AA in the tilápia fillets (Perini et al., 2010).

The changes in LA and LNA fatty acids in the treatments led to a decrease in the n-6:n-3 ratio. According to Simopoulos (2011), the scientific literature suggests that there has been an improvement in human diet; it used to have n-6:n-3 ratio of $1: 1$, but today the (mainly Western diets) ratios range from $10: 1$ to $25: 1$ ). These data indicate that current diets have low levels of n-3 fatty acids, which can causing many problems in the human body because they are important components of cell membranes. The n-6:n-3 balance is essential for the maintenance of normal development and homeostasis throughout the life cycle. Visentainer et al. (2005) reports that high values of the $n-6: n-3$ ratio generate an imbalance of fatty acids in the human body and probably contribute to the development of inflammatory processes, immune system disorders, hypertension, and neurological disorders. During 
Nishiyama et al.

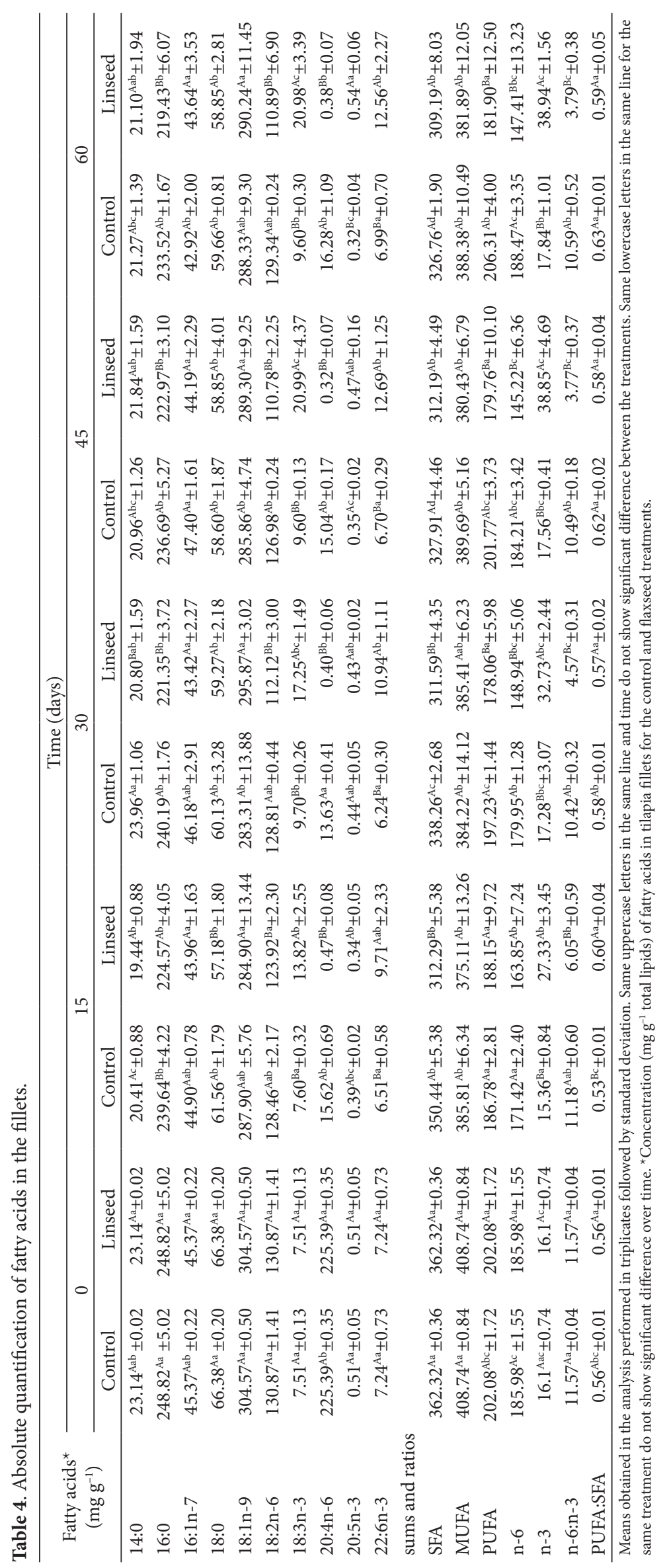


this experiment, the diet with flaxseed showed an n-6:n-3 ratio ranging from 11.6:1 to 3.8:1; the latter was observed after 45 days of cultivation. Ramos Filho et al. (2008) found the n-6:n-3 ratio of 3.65 for other freshwater fish such as Piaractus mesopotamicus.

The PUFA: SFA ratio remained constant for the fish fed the flaxseed diet. According to Enser et al. (1998), the expected value for PUFA:SFA must be greater than 0.45 since according to these authors, lower ratios indicate unhealthy meat, especially in terms of cardiovascular disease risk. Accordingly, foods with higher PUFA:SFA indicate higher nutritional value.

\section{Conclusion}

The addition of flaxseed flour in the diet of tilapia provided incorporation of satisfactory levels of $n-3$ fatty acids. Increased levels of omega 3 fatty acids in the fish muscle tissue were observed during the time the fish were fed the experimental flaxseed diet.

A time period of 45 days was enough to produce a distinctive fish. There were increases in the levels of LNA, EPA, and DHA in the fish fed flaxseed flour, but a lower n6:n3 ratio was found. Therefore, the dietary supplementation with flaxseed and the period of time it was given contributed to increase the nutritional quality of the fatty acids in tilapia muscle tissue. Analyzing PC1 and PC2, the time periods of 15 and 60 days of the flaxseed treatment showed positive contributions to the total content of n-3, LNA and DHA, highlighting the effect of incorporation of omega 3 fatty acids through supplementation with flaxseed flour.

\section{Acknowledgements}

The authors would like to thank Capes, CNPq and the Araucaria Foundation for financial support and the State University of Maringa for the availability of resources and technology for the development of this research.

\section{References}

Aguiar, A. C., Cottica, S. M., Boroski, M., Sargi, S. C., Prado, I. N., Bonafé, E. G., França, P. B., Souza, N. E., \& Visentainer, J. V. (2011). Effects of the flaxseed oil on the fatty acid composition of tilapia heads. European Journal of Lipid Science and Technology, 113(2), 269-274. http://dx.doi.org/10.1002/ejlt.201000035

Bahurmiz, O. M., \& Ng, W. K. (2007). Effects of dietary palm oil source on growth, tissue fatty acid composition and nutriaent digestibility of red hybrid tilapia, Oreochromis sp., raised from stocking to marketable size. Aquaculture, 262(2-4), 382-392. http://dx.doi. org/10.1016/j.aquaculture.2006.11.023

Blanchet, C., Lucas, M., Julien, P., Morin, R., Gingras, S., \& Dewailly, E. (2005). Fatty acid composition of wild and farmed atlantic salmon (Salmon salar) and rainbow trout (Oncorhynchus mykiss). Lipids, 40(5), 529-531. PMid:16094864. http://dx.doi.org/10.1007/ s11745-005-1414-0

Bligh, E. G., \& Dyer, W. J. (1959). A rapid method of total lipid extraction and purification. Canadian Journal of Biochemistry and Physiology, 37(8), 911-917. PMid:13671378. http://dx.doi. org/10.1139/o59-099
Correia, P. R. M., \& Ferreira, M. C. (2007). Exploring chemometrical procedures for evaluating analytical data. Quimica Nova, 30(2), 481-487. http://dx.doi.org/10.1590/S0100-40422007000200042

Cunniff, P. A. (1998). Official methods of analysis of AOAC international. Arlington: AOAC. CD-ROM.

Enser, M., Hallett, K. G., Hewett, B., Fursey, G. A. J., Wood, J. D., \& Harrington, G. (1998). Fatty acid content and composition of UK beef and lamb muscle in relation to production system and implications for human nutrition. Meat Science, 49(3), 329-341. http://dx.doi.org/10.1016/S0309-1740(97)00144-7

Fuchs, R. H. B., Ribeiro, R. P., Matsushita, M., Tanamati, A. A. C., Bona, E., \& Souza, A. H. P. (2013). Enhancement of the nutritional status of Nile tilápia (Oreochromis niloticus) croquettes by adding flaxseed flour. LWT - Food Science and Technology, 54(2), 440-446. http:// dx.doi.org/10.1016/j.lwt.2013.07.004

Givens, D. I., \& Gibbs, R. A. (2006). Very long chain n-3 polyunsaturated fatty acids in the food chain in the UK and the potential of animalderived foods to increase intake. Nutrition Bulletin, 31(2), 104-110. http://dx.doi.org/10.1111/j.1467-3010.2006.00554.x

Hartman, L., \& Lago, R. C. A. (1973). Rapid preparation of fatty acid methyl esters from lipids. Laboratory Practice, 22(6), 475-477. PMid:4727126.

Joseph, J. D., \& Ackman, R. (1992). Capillary column gas chromatographic method for analysis of encapsulated fish oils and fish oil ethyl esters: collaborative study. Journal of the American Oil Chemists' Society, 75(3), 488-506.

Justi, K. C., Hayashi, C., Visentainer, J. V., Souza, N. E., \& Matsushita, M. (2003). The influence of feed supple time on the fatty acid profile of Nile tilapia (Oreochromis niloticus) fed on a diet enriched with n-3 fatty acids. Food Chemistry, 80(1), 489-493. http://dx.doi. org/10.1016/S0308-8146(02)00317-5

Kirkhus, B., Lamglait, A., Eilertsen, K. E., Falch, E., Haider, T., Vik, H., Hoem, N., Hagve, T. A., Basu, S., Olsen, E., Seljeflot, I., Nyberg, L., Elind, E., \& Ulven, S. M. (2012). Effects of similar intakes of marine $n$-3 fatty acids from enriched food products and fish oil on cardiovascular risk markers in healthy human subjects. British Journal Nutrition, 107(9), 1339-1349. PMid:21917191. http://dx.doi. org/10.1017/S0007114511004508

Luciano, G., \& Naes, T. (2009). Interpreting sensory data by combining principal component analysis and analysis of variance. Food Quality and Preference, 20(3), 167-175. http://dx.doi.org/10.1016/j. foodqual.2008.08.003

Luzia, L. A., Sampaio, G. R., Castellucci, C. M. N., \& Torres, E. A. F. S. (2003). The influence of season on the lipid profiles of five commercially important species of Brazilian fish. Food Chemistry, 83(1), 93-97. http://dx.doi.org/10.1016/S0308-8146(03)00054-2

Mateos, H. T., Lewandowski, P. A., \& Su, X. Q. (2012). Effects of dietary fish oil replacement with flaxseed oil on tissue fatty acid composition and expression of desaturase and elongase genes. Journal of the Science of Food and Agriculture, 92(2), 418-426. PMid:21834099. http://dx.doi.org/10.1002/jsfa.4594

Matos, G. D., Pereira-Filho, E. D., Poppi, R. J., \& Arruda, M. A. Z. (2003). Análise exploratória em química analítica com emprego de quimiometria: PCA e PCA de imagens. Revista Analytica, (6), 38-50.

Matsushita, M., Justi, K. C., Padre, R. G., Milinsk, M. C., Carmino, H., Gomes, S. T. M., Visentainer, J. V., \& Souza, N. E. (2006). Influence of diets enriched with different vegetable oils on the performance and fatty acid profile of Nile tilapia (Oreochromis niloticus) fingerlings. Acta Scientiarum Technology, 28(2), 125-131. 
National Research Council - NRC. (1993). Nutrient requirements of fish. Washington.

Ottestad, I., Hassani, S., Borge, G. I., Kohler, A., Vogt, G., Hyötyläinen, T., Oresic, M., Bronner, K. W., Holven, K. B., Ulven, S. M., \& Myhrstad, M. C. W. (2012). Fish oil supplementation alters the plasma lipidomic profile and increases long-chain pufas of phospholipids and triglycerides in healthy subjects. PLoS One, 7(8), 1-11. PMid:22952598 PMCid:PMC3429454. http://dx.doi. org/10.1371/journal.pone.0042550

Pagamunici, L. M., Gohara, A. K., Souza, A. H. P., Bittencourt, P. R. S., Torquato, A. S., Batiston, W. P., Gomes, S. T. M., Souza, N. E., Visentainer, J. V., \& Matsushita, M. (2014a). Using chemometric techniques to characterize gluten-free cookies containing the whole flour of a new quinoa cultivar. Journal of the Brazilian Chemical Society, 25(2), 219-228.

Pagamunici, L. M., Souza, A. H. P., Gohara, A. K., Silvestre, A. A. F., Visentainer, J. V., Souza, N. E., Gomes, S. T., \& Matsushita, M. (2014b). Multivariate study and regression analysis of gluten-free granola. Food Science and Technology, 34(1), 127-134.

Perini, J. A. L., Stevanato, F. B., Sargi, S. C., Visentainer, J. E. L., Dalailo, M. M. O., Matsushita, M., Souza, N. E., \& Visentainer, J. V. (2010). Omega-3 and omega- 6 polyunsaturated fatty acids: metabolism in mammals and immune response. Revista de Nutrição, 23(6), 1075-1086. http://dx.doi.org/10.1590/S1415-52732010000600013

Ramos Filho, M. M., Ramos, M. I. L., Hiane, P. A., \& Souza, E. M. T. (2008). Lipid profile of four species of fish from the pantanal region of Mato Grosso do Sul. Food Science and Technology, 28(2), 361-365.

Ratnayake, W. M., \& Galli, C. (2009). Fat and fatty acid terminology, methods of analysis and fat digestion and metabolism: a background review paper. Annals of Nutrition and Metabolism, 55(1-3), 8-43. PMid:19752534. http://dx.doi.org/10.1159/000228994

Ryan, E., Galvin, K., O’Connor, T. P., \& Maguire, A. R. (2007). Phytosterol, squalene, tocopherol content and fatty acid profile of selected seeds, grains, and legumes. Plant Foods for Human Nutrition, 62(3), 85-91. PMid:17594521. http://dx.doi.org/10.1007/ s11130-007-0046-8
Simões, M. R., Ribeiro, C. F. A., Ribeiro, S. C. A., Park, K. J., \& Murr, F. E. X. (2007). Physicochemical and microbiological composition and yield of thai-style tilapia fillets (Oreochromis niloticus). Food Science and Technology, 27(3), 608-613.

Simopoulos, A. P. (2011). Evolutionary aspects of diet: the omega-6/ omega-3 ratio and the brain. Molecular Neurobiology, 44(2), 203215. PMid:21279554. http://dx.doi.org/10.1007/s12035-010-8162-0

Souza, A. H. P., Gohara, A. K., Pagamunici, L. M., Visentainer, J. V., Souza, N.E., \& Matsushita, M. (2014). Development, characterization and chemometric analysis of gluten-free granolas containing whole flour of pseudo-cereals new cultivars. Acta Scientiarum Technology, 36(1), 157-163. http://dx.doi.org/10.4025/19195

StatSoft. (2007). Statistica: data analysis software system. version 8.0. Tulsa.

Tonial, I. B., Stevanato, F. B., Matsushita, M., Souza, N. E., Furuya, W. M., \& Visentainer, J. V. (2009). Optimization of flaxseed oil feeding time and length in adult Nile tilapia (Oreochromis niloticus) as a function of muscle Omega 3 fatty acids composition. Aquaculture Nutrition, 15(6), 564-568. http://dx.doi.org/10.1111/j.13652095.2008.00623.x

Visentainer, J. V., Gomes, S. T. M., Hayashi, C., Santos-Júnior, O. O., Silva, A. B. M., Justi, K. C., Souza, N. E., \& Matsushita, M. (2003). Effect of ration supply time with flaxseed oil on physico-chemical composition and fatty acids of Nile tilapia (Oreochromis niloticus) heads. Food Science and Technology, 23(3), 478-484.

Visentainer, J. V., Souza, N. E., Matsushita, M., Hayashi, C., \& Franco, M. R. B. (2005). Influence of diets enriched with flaxseed oil on the a-linolenic, eicosapentaenoic and docosahexaenoic fatty acid in Nile tilapia (Oreochromis niloticus). Food Chemistry, 90(4), 557-560. http://dx.doi.org/10.1016/j.foodchem.2004.05.016

Zanqui, A. B., Maruyama, S. A., Barilli, D. J., Ribeiro, S. A. O., Gomes, S. T. M., Visentainer, J. V., Souza, N. E., Boscolo, W. R., \& Matsushita, M. (2013). Incorporation of conjugated linoleic and alpha linolenic fatty acids into Pimedolus maculatus fillets. Food Science and Technology, 33(3), 532-540. 